\title{
Keratoacanthoma, Verruca Vulgaris Arising over Porokeratosis of Mibelli : A New Association
}

\author{
ATM Asaduzzaman ${ }^{1}$, Mohammad Lutfur Rahman Rahat ${ }^{2}$, Mohammad Jamal Uddin³, \\ Mohammod Abu Hena Chowdhury ${ }^{4}$, AKM Rejaul Haque ${ }^{5}$
}

\begin{abstract}
Introduction: This case report highlighting the presence of keratoacanthoma and verruca vulgaris over the lesion of porokeratosis of mibelli. Case Report: In this case a 50-year-old housewife came with large well-defined asymptomatic plaque over the upper part of back of the trunk for last 10 years. After evaluation we got the presence of keratoacanthoma and verruca vulgaris on the plaque of porokeratosis of mibelli. Discussion: Porokeratosis is a clonal expansion of keratinocytes. Among the neoplasm squmous cell carcinoma (SCC) is the most commonly reported malignancy in porokeratosis. But in our case we didn't find lesion of SCC. Porokeratosis of Mibelli, Keratoacanthoma and Verruca vulgaris have an association with human papilloma virus(HPV). This eithopathogenesis may be related to our clinical finding. Conclusion: There were reporting of squmous cell carcinoma or keratoacanthoma on Porokeratosis of Mibelli. But in our case we found both Keratoacanthoma and Verruca Vulgaris over Porokeratosis of Mibelli.
\end{abstract}

Key words: Porokeratosis of Mibelli, Keratoacanthoma, Verruca Vulgaris.

Number of Figures: 06; Number of References: 17; Number of Correspondence: 05.

\section{Dr. ATM Asaduzzaman}

Associate Professor

Department of Dermatology

Bangabandhu Sheikh Mujib Medical University Dhaka, Bangladesh.

2. Dr. Mohammad Lutfur Rahman Rahat Medical Officer

Central Skin and Social Hygiene Center Agrabad, Chittagong.

*3. Corresponding Author:

Dr. Mohammad Jamal Uddin

Associate Professor

Department of Dermatology and Venereology

Bangabandhu Sheikh Mujib Medical University

Dhaka, Bangladesh.

E mail: jamalbsmmu@yahoo.com

Ph. +88-01729225300

4. Dr. Mohammod Abu Hena Chowdhury

Associate Professor

Department of Dermatology

Bangabandhu Sheikh Mujib Medical University

Dhaka, Bangladesh.

5. Dr. AKM Rejaul Haque

Associate Professor

Department of Dermatology

Bangabandhu Sheikh Mujib Medical University

Dhaka, Bangladesh.

\section{Introduction}

Porokeratosis refers to a heterogeneous group of keratinization disorders, in which the presence of a so called 'cornoid lamella' in a lesion can be seen ${ }^{1}$. On the other hand, keratoacanthoma is a rapidly evolving tumour of the skin, composed of keratinizing squamous cells originating in pilosebaceous follicles and resolving spontaneously if untreated ${ }^{2}$. Verruca vulgaris are benign tumours caused by infection of keratinocytes with HPV, visible as well defined hyperkeratotic protrusions ${ }^{3}$. Here we are reporting a case of Keratoacanthoma, Verruca vulgaris in a lesion of Porokeratosis of Mibelli.

\section{Case report}

Mrs. Mojiron, 50-year-old housewife, normotensive, nondiabetic hailing from Gendari, Tangail presented to us with a large well-defined asymptomatic plaque over the upper part of back of the trunk for last 10 years. Initially she developed a small papule over her left shoulder, which spreads peripherally, involving her left upper back and part of right upper back of the trunk. She also complained of development of multiple asymptomatic exophytic nodules with warty surface and some smooth dome shaped nodules within the plaque for last two years. There were no history of pain, bleeding on lesional area. There were no history of fever, joint pain, photosensitivity and any symptoms pertaining to other systemic illness. She was a mother of four sons. None of her family members were affected by such condition. Patient was mildly anemic, no lymphadenopathy or organomegaly.

There was a well-defined large plaque about $(27 \times 18) \mathrm{cm}$ in diameter situated over left shoulder, left upper back and part of right upper back. Plaque was irregular in outline and surrounded by raised fine keratotic elevated border with a central groove. The enclosed central portion is dry, dyspigmented, scaly and atrophic in some places. 
There were multiple dyspigmented nodules of different sizes were situated within the large plaque. Largest one was approx.20-25 $\mathrm{mm}$ in size. Nodules were firm, smooth, shiny and dome shaped. One of them had smooth crater filled with a central keratin plaque situated on the left upper back.

There were some large well-defined plaques situated within and at the margin of the initial large plaque, some of these plaques had verrucous and some had scaly surface. They were hypopigmented to erythematous in color and firm in consistency. There were no active bleeding or discharge on the lesions (figure: 1 ).

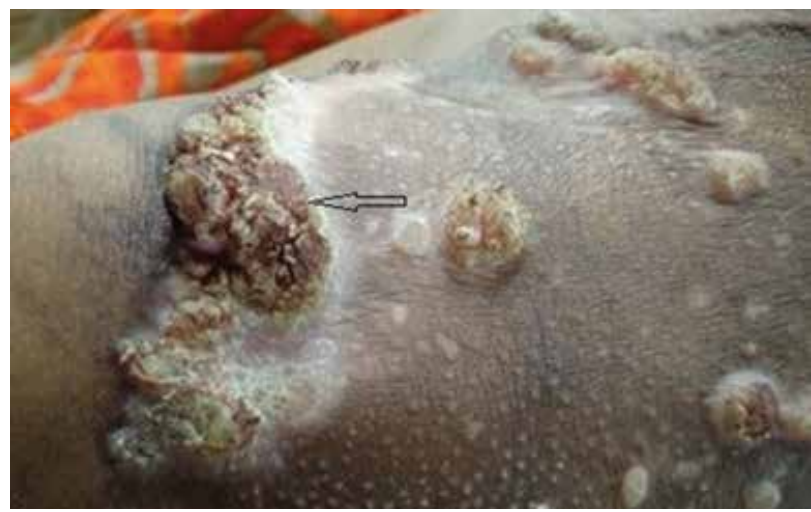

Figure-1: Large plaque with raised fine keratotic border with dome shaped papule with central crater with verrucous surface.

There was a large exophytic nodule with verrucous upper surface and erythematous lateral surface with a collar at the base measuring about $7 \mathrm{~cm}$ (approx.) in length and $4 \mathrm{~cm}$ (approx) in width at base (figure :2).

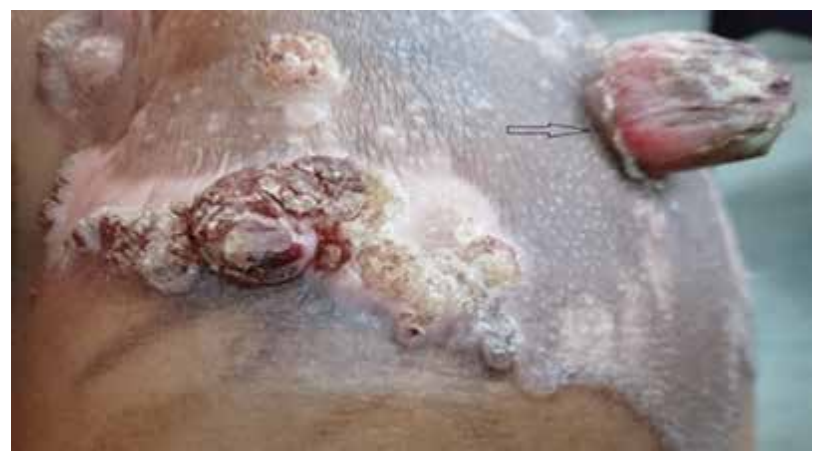

Figure-2: Exophytic nodule with verrucous upper surface.

With the above scenario our provisional diagnosis was Porokeratosis of Mibeli with Keratoacanthoma with Verruca vulgaris. Our differential diagnoses were Keratoacanthoma centrifugum marginatum, Squamous cell carcinoma, cutaneous horn and Porokeratoma.

We performed an excisional biopsy of a crateriform nodule and Verrucous plaque. A $4 \mathrm{~mm}$ incisional biopsy was also taken from the border of the porokeratotic plaque of the patient.

Histopathology of section taken from crateriform nodule reveal a keratoacanthoma. It reveals marked hyperkeratosis (figure :3).

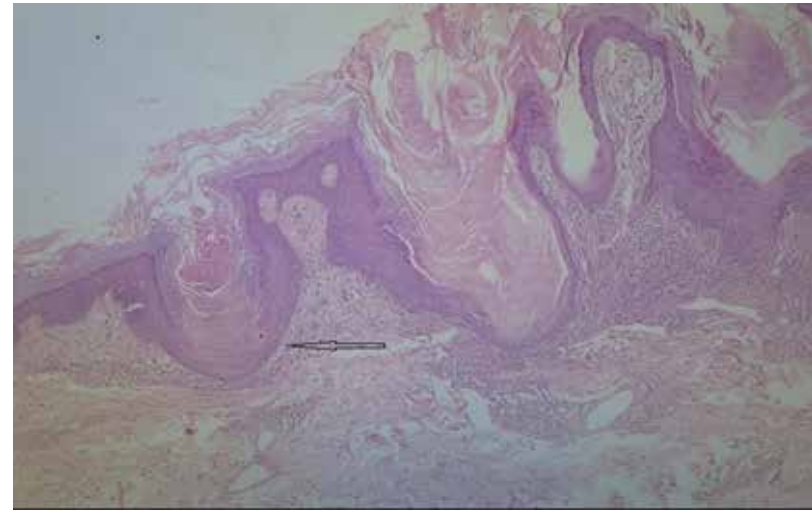

Figure-3: Hyperkeratosis and Keratin-filled crater.

Histopathology of section taken from Verrucous plaque reveal a verruca vulgaris It shows a papillary process, hyperkeratosis, parakeratosis and Koilocytes (figure:4).

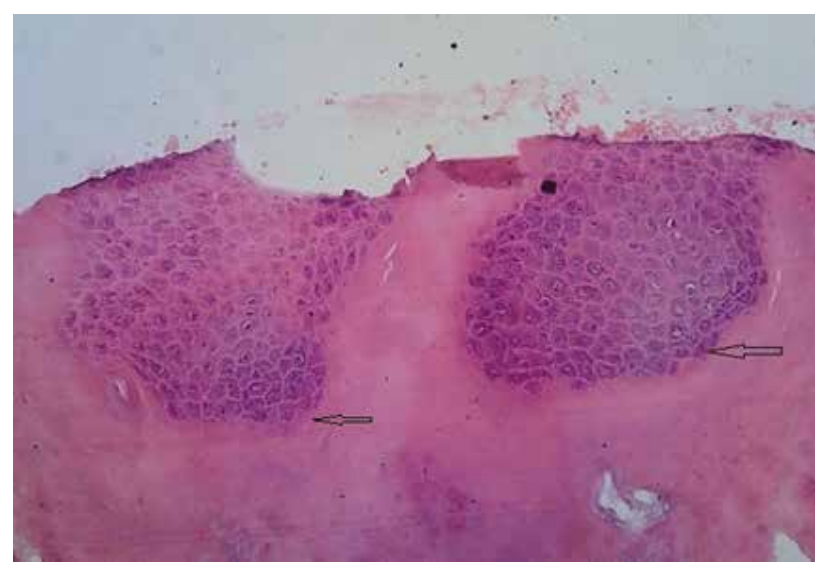

Figure-4: Hyperkeratosis with Koilocytes.

Histopathology of section taken from the margin of Porokeratotic border showed oblique invagination containing coronoid lamella. The squamous cells in the base of invagination shows mild dyskeratosis. The dermis contains moderate perivascular infiltration of chronic inflammatory cells (figure:5).

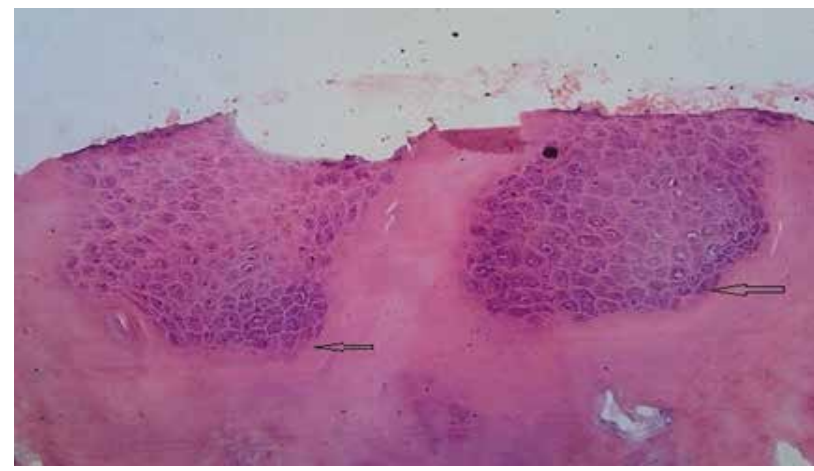

Figure-5: Coronoid lamella with absent granular layer.

On the basis of the benign course of the presenting lesion and clinicopathological features, our final diagnosis was Keratoacanthoma,Verruca vulgaris arising over Porokeratosis of Mibelli. 
Considering the scenario, we treated the patient with systemic Acitretin 50mg daily for 3 months (figure: 6) followed by $25 \mathrm{mg}$ daily for one year. Patient improved symptomatically and is under regular follow-up.

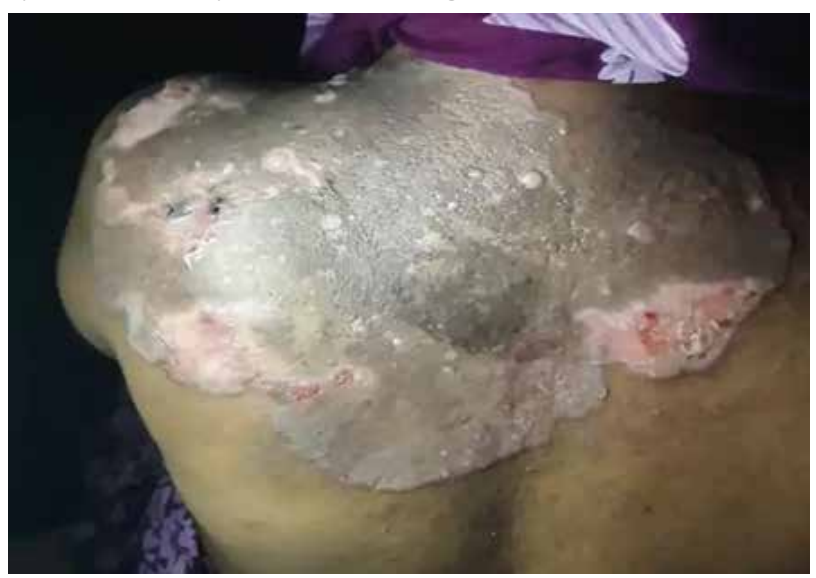

Figure-6: Lesional area after 3 months of treatment.

\section{Discussion:}

A porokeratosis is a clonal expansion of keratinocytes which differentiate abnormally but are not hyperproliferative. Porokeratoses may present as single or multiple lesions and may be localized or disseminated. All forms show a thin column of parakeratosis, the cornoid lamella, representing the active border ${ }^{4,5}$. Porokeratosis of Mibelli starts as a single or small group of keratotic papules which may be pigmented. These gradually grow over years to form one or more irregular plaques with a thin, keratotic and well demarcated border. The central area may be atrophic, either hyper or hypopigmented, hairless and anhidrotic. Occasionally, giant and verrucous forms of the disease may occur. Lesions are generally distributed on the extremities but can occur anywhere on the body ${ }^{6}$. It usually begins during infancy or childhood. Inheritance is usually autosomal dominant $^{7}$. Squmous cell carcinoma is the most commonly reported malignancy in porokeratosis. Other associated neoplasms reported are Bowen's disease, basal cell carcinoma, diffuse large B cell lymphoma, and others ${ }^{7,8}$.

Keratoacanthomas are exoendophytic lesions with an invaginating mass of keratinizing, well differentiated squamous epithelium present at the sides and bottom of the lesion. There is a central keratin filled crater which enlarges with the maturation as well as the evolution of the lesion. Another diagnostic feature is the lipping or buttressing of the edges of the lesion which overlap the central crater, giving it a symmetrical appearance. Epithelial atypia and mitoses are not usual features. There may be a moderately heavy mixed infiltrate of inflammatory cells in the adjacent dermis, and this is often moderately heavy. Histological features which favor a diagnosis of keratoacanthoma over squamous cell carcinoma, low power architecture with a flask like configuration and central keratin plug, as well as the pattern of cell keratinization with large central cells with eosinophilic cytoplasm ${ }^{9}$.The exact etiopathogenesis of keratoacanthoma is unclear; however, suspected inciting factors include ultraviolet light, genetic factors, immunosuppression, chemical carcinogens, viruses, various types of mechanical trauma, or it may arise secondary to other skin lesions such as psoriasis, discoid lupus erythematosus, herpes zoster, lichen planus, seborrheic dermatitis, pemphigus foliaceus, and others cell carcinoma (SCC) include the characteristic ${ }^{10,11,12}$.

Verruca vulgaris is the general wart of the skin frequently located on hands, fingers, knees and elbows. It is primarily related to three important human papilloma viruses HPV-2, HPV-4, and HPV-40. HPV causes a restricted growth in the superficial layer of the skin and thus verruca vulgaris is hyperkeratotic, exophytic, dome shaped papules or nodules. The lesions are typically sessile, verrucous with discrete borders. HPV essentially causes intraepithelial extended infectious cycle with no cell death or viraemia ${ }^{13}$.

We are reporting a rare association of Porokeratoses of Mibelli, Keratoacanthoma and Vertruca vulgaris in as same lesion. Former studies have indicated an association of Porokeratoses of Mibelli with Keratoacanthoma ${ }^{14}$. However till date no case of Verruca vulgaris has been reported to appear over Porokeratosis of Mibelli. In Keratoacanthoma, human papilloma virus like particles has been demonstrated but no predominant HPV type has been found ${ }^{15,16}$. In Porokeratoses of Mibelli evidence of HPV types 66 and 14 respectively were described ${ }^{17}$. Such a disease association is rare and it may be related to HPV. Therefore, we suggest any suspicious skin lesion in porokeratosis of mibelli needs Immunohistochemistry or immunocytochemistry using type common or type-specific antibodies and Polymerase Chain Reaction for HPV DNA.

Conflict of Interest: None.

\section{Acknowledgement:}

We are grateful to the entire staff of Department of Dermatology and Department Patholgy, Bangabandhu Sheikh Mujib Medical University, Shahbag, Dhaka for their cooperation and support during this study.

\section{References:}

1. Sertznig P, Von Felbert V, Megahed M. Porokeratosis: present concepts. J Eur Acad Dermatol Venereol. 2012; 26:404-12

https://doi.org/10.1111/j.1468-3083.2011.04275.x

PMid:21929548

2. LeBoit PE, Burg G, Weedon D, Sarasain A, eds. World Health Organization Classifi cation of Tumours. Pathology and Genetics of Skin Tumours. Lyon: IARC Press; 2008: 1- 47.

3. Griffiths C, Barker J, Bleiker TO, Chalmers R, Creamer D, editors. Rook's textbook of dermatology. John Wiley \& Sons; 2016 Feb 29.

https://doi.org/10.1002/9781118441213 
4. Ferreira FR, Nogueira Santos LD, Nogueira Mendes Tagliarini FA, Lanzoni de Alvarenga Lira M. Porokeratosis of Mibelli: literature review and a case report. An Bras Dermatol. 2013;88(6 Suppl. 1):179-82.

https://doi.org/10.1590/abd1806-4841.20132721

\section{PMid:24346913 PMCid:PMC3876017}

5. Dover JS, Phillips TJ, Burns DA. Disseminated superficial actinic porokeratosis: coexistence with other porokeratotic variants. Arch Dermatol. 1986; 122:887-9.

https://doi.org/10.1001/archderm.122.8.887

https://doi.org/10.1001/archderm.1986.01660200059015

PMid:3740871

6. Chu AC, Teixeira F. Acquired disorders of epidermal keratinization. Rook's Textbook of Dermatology, Ninth Edition. 2016 Jul 15:1-34.

7. Sarma N, Boler AK, Bhattacharya SR. Familial disseminated plaque type porokeratosis with multiple horns and squamous cell carcinoma involving anal skin. Indian J Dermatol Venereol Leprol. 2009; 75:551.

https://doi.org/10.4103/0378-6323.55427

PMid: 19736460

8. Batalla A, Roson E, De la Torre C. Porokeratoma: A different entity or a variant of verrucous (hyperkeratotic) porokeratosis? Indian J Dermatol. 2013; 58:158.

https://doi.org/10.4103/0019-5154.108073

PMid:23716820 PMCid:PMC3657230

9. Weedon D. Weedon's Skin Pathology. 3rd ed. London: Churchill Livingstone Elsevier; 2010.

10. Cerroni L, Kerl H. Keratoacanthoma. In: Wolff K, Goldsmith LA, Katz SI, Gilchrest BA, Paller AS, Leffell DJ, editors. Fitzpatrick's Dermatology in General Medicine. 7th ed. New York: McGraw Hill; 2008: 104953. 11. Janik JP, Bang RH. Traumatic keratoacanthoma arising in a 15 year old boy following a motor vehicle accident. Pediatr Dermatol. 2006; 23:448 50.

https://doi.org/10.1111/j.1525-1470.2006.00280.x

PMid:17014639
12. Hadley JC, Tristani Firouzi P, Florell SF, Bowen GM, Hadley ML. Case series of multiple recurrent reactive keratoacanthomas developing at surgical margins. Dermatol Surg. 2009; 35:2019:24.

https://doi.org/10.1111/j.1524-4725.2009.01327.x

PMid:19758354

13. 13th Global Dermatologists Congress Human papilloma virus induced molecular pathogenesis of verruca vulgaris Satadal Das and Swami, Moscow, Russia. 2018 July 23- 24.

14. Bhunia D, Ghosh S, Rudra O, Biswas S, Agarwal M, Ghosh A. Keratoacanthoma arising over margin of porokeratosis of mibelli: A new association? Indian Journal of Dermatology. 2016;61(1).

https://doi.org/10.4103/0019-5154.174061

PMid:26955114 PMCid:PMC4763623

15. Li J, Wang K, Gao F. Array comparative genomic hybridization of keratoacanthomas and squamous cell carcinomas: different patterns of genetic aberrations suggest two distinct entities. J Invest Dermatol. 2012; 132: $2060-6$.

https://doi.org/10.1038/jid.2012.104

PMid:22534878

16. Forslund O, DeAngelis PM, Beigi M, Schjolberg AR, Clausen OP. Identifi cation of human papillomavirus in keratoacanthomas. J Cutan Pathol. 2003; 30: 423 - 9.

https://doi.org/10.1034/j.1600-0560.2003.00092.x

PMid:12859739

17. Esser AC, Pittelkow MR, Randle HW. Human papillomavirus isolated from transplant-associated porokeratoses of mibelli responsive to topical 5\% imiquimod cream. Dermatologic surgery. 2006 Jun 1;32(6):858-61.

https://doi.org/10.1111/j.1524-4725.2006.32176.x

PMid:16792657 